\title{
Chemical Whiteness
}

Young men and women, all dressed in white, take over the central plaza of a sprawling shopping mall in Metro Manila, and begin dancing energetically to upbeat music. When the song is over, they pick up large signs and together form advertisement for Lactacyd White Intimate, a new version of Lactacyd's vaginal wash. The next song begins, and the youth start to resume their sexy dance moves. More people stand around and watch, and when the dancing ends again, then banners are raised once more. Type "Lactacyd White Intimate Flash Mob” into YouTube's search bar, and you can see a number of videos of flash mobs done in and around Metro Manila (Fig. 5.1).

Why is Lactacyd promoting the whitening of vaginas? Our ethnographies on skin whitening across multiple urban sites in Indonesia and the Philippines show how whiteness is associated with confidence and cleanliness, ideas which Lactacyd mobilizes to promote its vaginal wash, as do other companies that sell personal care products. Content analysis of advertisements reveals that "good" skin is presented as young, smooth, pore-less, bright, and "white"; while "bad" skin is dark, dry, and rough ( $\mathrm{Li}$ et al. 2008). In disseminating these ideas, companies 


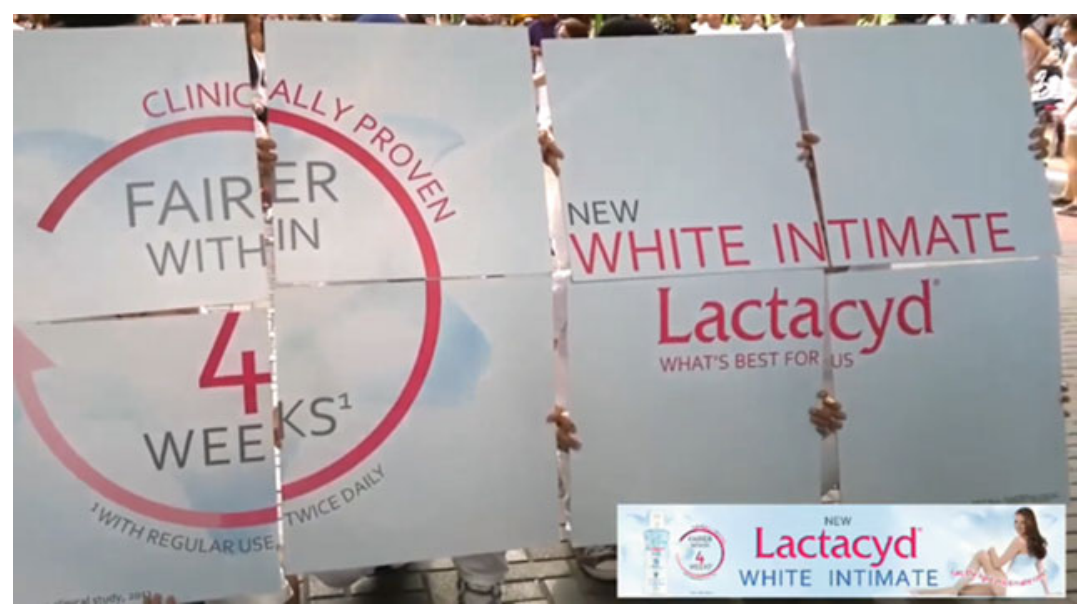

Fig. 5.1 Screenshot of the signs held up by the young flash mob dancers (Source Photo taken by Anita Hardon, January 10, 2019 from Lactacyd White Intimate Flash Mob video, Vengill Gutierrez 2012)

such as Lactacyd, Unilever, and L'Oréal perpetuate and reinforce prevailing notions of colorism (Glenn 2008), in which white skin signals, youthfulness, success, confidence, and beauty.

Historical analysis shows that the privileging of lighter skin in the Philippines and Indonesia reaches back to pre-colonial times. Abrera (2009) studied pre-colonial texts that describe how women who belonged to the chiefdoms were veiled since childhood and thus stayed lighter skinned; their light skin was a marker of their elite status, as they did not have to engage in agricultural labor under the scorching Filipino sun. American, Spanish, and Dutch colonizers reinforced such pre-existing hierarchies. Thompson (2013) writes about how American colonizers praised the light skin and beauty of elite women (who generally had some Spanish ancestors), assigning to them a level of civilization equal to the best of American and European society, while lower-class Filipinas were described as brown, ugly, and uncivilized. Reports of similar color coding are found in Indonesian historical sources. In her reading of the ninth-century Javanese adaptation of the epic Indian poem Ramayana, Saraswati (2013) shows how light women were presented as desirable, likened to the whiteness and brightness of the moon, 
while evil characters were black-skinned. The epic poem also describes women using the pollen of pandanus palms as a whitening face powder; nowadays their descendants use Johnson's Baby Powder.

White skin privileging is not only done through the dissemination of ideas. It is also done in everyday interactions, in which darker skin is disvalued, leaving those with it feeling ashamed. In a fascinating analysis of skin-whitening among 46 Indonesian women from Jakarta and the rural town of Balikpapan, Saraswati (2013) discusses how the cultural preference for white skin is reflected in peer-to-peer interactions. One of her informants, Nina, who worked in a fitness clubs, said that her colleagues often commented, "Goodness, you have the darkest skin," which made her feel insecure in her job. Other informants told Saraswati (2013) similar stories, such as Ina, a 32-year-old, who said, "When I had to meet with many people and my skin was dark. I didn't feel confident," (p. 115) and Wati, a 30-year-old, who explained, "Because I was born dark-brown, I didn't have self-confidence. So I whiten my skin to be more confident" (p. 115). Saraswati concludes that women's use of facial lightening creams was driven by a profound desire to feel confident, and to avoid shame and embarrassment.

Colorism is perpetuated in everyday interactions between people and their skin-whitening products, making up what Markus and Conner (2013) refer to as the "culture cycle." Explaining how these daily and mundane interactions are shaped by economic, legal, and religious institutions as well as by underlying colorist ideas, the authors suggest that the cycle can be broken if we become aware of the messages in our everyday environment and the institutional regimes that shape our behavior. Such awareness can be the basis for "doing" race differently, which is not an easy thing to do, as it means intervening in complex systems of ideas and practices that link character and intellectual capacity to skin tone, and taking on cultural, representational, and institutional dynamics that perpetuate colorist dynamics (Moya and Markus 2010). 


\section{Investing in Whiteness}

Our ethnographies show that having light skin takes on a specific value in interactions in the service sector, where lighter skin can attract clients and thus have economic value. Skin lightening made our interlocutors feel more confident in their interactions with their clients, and they believed that having lighter skin helped them compete for jobs. Indeed, having light skin does increase one's chance of getting a job in malls, given discriminatory institutional policies that add to the precariousness of youth not born with light skin. These ideas, interactions, and discriminatory work policies are not just harmful because they perpetuate a culture cycle (Markus and Conner 2013) that privileges having white skin and discriminates against people of color. They are also harmful because many of the skin-whitening products contain toxic chemicals, which can disfigure and can cause potentially life-threatening metabolic disturbances. Thus, this chapter examines the distinct nature of interpersonal dynamics in the service sector, institutional policies that perpetuate colorism, the chemical content of skin-whitening products, as well as the colorist scripts that companies use to market them. The chapter attends to the highly material work that service sector workers " $d o$ " in order to present the white skin that their employers expect them to embody. We also analyze relevant gender dynamics, showing how young men in the Philippines are competing with women for service sector jobs, which has led to their new use of skin whiteners. We end the chapter with a description of some of the arts initiatives organized by the ChemicalYouth project to both celebrate skin diversity and raise awareness of the cultural notions and institutional dynamics that perpetuate skin tone-based inequality.

Social scholars have emphasized the "immaterial" nature of labor in the service sector, in contrast to the material nature of manufacturing (Leidner 1999; Hardt and Negri 2000; Oksala 2016). Service sector workers manage affects and desires, and are trained to perform certain scripts to encourage customers to buy. Often cited as illustration is Hochschild's (1983) fascinating analysis of the "acting" done by flight attendants, who must put on a smile even when they don't feel like it. Such emotional labor, Hochschild argues, is alienating, because it 
demands that workers perform empathy that they do not feel. Farrugia (2018) draws attention to the particular relevance of youthfulness in the service sector, describing it as a "heterogeneous quality produced within forms of sociality that are enacted both within and outside of the formal labour relation, and that is infused with meaning and intensity through the process of immaterial labour" (p. 516). He argues that youthfulness in this context is produced as an "affective capacity for playful enjoyment, cutting edge taste-making, savvy consumption and desirable embodiment" (Farrugia 2018, p. 516).

While our ethnographies underscore the immaterial and affective work conducted by young people in the service sector, we found that they also did highly material work to achieve the "desirable embodiment" of having a fair skin. Our interlocutors bought a range of products to lighten their faces and bodies, in order to present the eternal youth promised by the products they sold (see also Chua 2000; Lan 2001 on this issue). Human resource agents select job applicants with light skin for service sector jobs, and also demand that their workers "retouch" their faces regularly while interacting with the public.

The investment in whitening skin by service sector workers can be understood economically, as a form of investment, which generates biocapital. When seeking to address the colorist notion involved in the skin-whitening practices of service sector workers, we need to attend to the economic logic at stake in this institutional setting. ${ }^{1}$ But, our ethnographies show, achieving lightness is taxing, just as the flight attendants' acting is. Changing one's skin tone and texture is hard work that has to be repeated every day, and it comes with health risks. Our female informants used multiple products on a daily basis, applying them in layers: soap, then skin creams and lotions, then foundations and powders. Many of our interlocutors were unsure if the soaps, creams, and lotions really did lighten their skin, and they kept on switching brands to find one that worked better.

The accumulated biocapital, moreover, readily fades, however, as exposure to daylight leads to greater melanin and thus darker skin tones. Hence skin-lightening regimens need to be repeated over and over again. The more effective skin-lightening products, such as exfoliating 
products containing hydroquinone, and skin creams containing melanindisabling mercury, also have severe long-term adverse effects, including skin cancer and disruptions to the production of melanin, evident as blackspots. Our interlocutors' investments in biocapital were many, exacerbating the already-precarious economic states of service sector workers. Further, as their skin deteriorated, their chances of having their contract renewed and attracting clients decreased, further increasing skin tone-based inequalities, rather than diminishing them.

\section{Toxic Whiteness}

The transnational companies that sell skin-whitening cosmetics have been criticized for degrading women with dark skin and thereby adding to racialized discrimination, as well as for including toxic chemicals in their products (Glenn 2008; Deacon 2011). In all the countries where ChemicalYouth conducted ethnographic research, governments rely on companies to police themselves. Food and drug authorities do not demand tests before a product enters the market. Rather, their safety is usually only regulated after there have been incidents.

Cosmetics contain thousands of chemicals, most of which have not been adequately tested, and though companies are expected to list contents on their labels, these often include general terms such as "fragrance." Commenting on consumer protection by the US Food and Drug Administration (FDA), David Michaels, professor at the George Washington University School of Public Health says in a recent documentary: "The FDA works very hard on drugs, on medical devices. Perhaps a little less well on food ... Protecting people from dangerous materials in cosmetics is not even in the backseat, not even in the car" (quoted in Ellis 2019).

Dangerous and toxic incidents occur regularly. For example, after we had discussed a draft of this chapter, one of my colleagues sent me an article from the Los Angeles Times that reported that a women from Sacramento had been hospitalized after using a bottle of Pond's cream she had bought from a pharmacy from Mexico (Reyes-Velarde 2019). She had gone to the emergency room with symptoms of numbness in her hands 
and face, finding it difficult to speak. County administrators tested the product, and found that it had very high levels of mercury, and tests of her blood revealed that she had 2630 micrograms of mercury per liter in her blood. A spokeswoman from Pond's said they do not use mercury in their products.

Mercury is one of the toxic chemicals often used in skin-lightening products. Hydroquinone is another. Both chemicals are only allowed in amounts under specified thresholds in cosmetics in Indonesia and the Philippines, but our studies show that commonly used skin-lightening products contain high levels of these chemicals. The World Health Organization warns that mercury causes skin rashes and scarring, as well as increased risks for cancer, because it reduces the protective function of melanin (a body chemical that gives color to skin, hair, and eyes). It can also damage the nervous, immune, and renal systems; the nervetingling sensation felt by the woman in the Los Angeles Times story may have been caused by mercury poisoning. Studies have furthermore linked elevated mercury levels in the body to endocrine disruptions, infertility, and miscarriage. Moreover, the chemical is transformed by bacteria into organic forms that accumulate in living organisms, which can affect the safety of our food.

In response to all of these serious adverse effects, countries from around the world signed onto the 2013 Minamata Convention, ${ }^{2}$ which bans the manufacture, import, and export of mercury-added skinlightening cosmetics with a mercury content over 1 part per million, including soaps and creams. National governments are expected to adopt legislation to ensure implementation of this ban by 2020 .

A survey by the Zero Mercury Working Group of the European Environmental Bureau (European Environmental Bureau 2018) found highly toxic levels of mercury in various products sampled in shops in Indonesia and the Philippines. For example, RDL Whitening Treatment Night cream, samples in Indonesia (and produced in the Philippines) was found to contain $5959 \mathrm{ppm}$, much higher than the $1 \mathrm{ppm}$ threshold. And Goree Beauty Cream (manufactured in Pakistan), bought in a Philippines store, was found to have a mercury content of $10.576 \mathrm{ppm}$. The Ecological Waste Coalition of the Philippines (EcoWaste Coalition), 
an alliance of school, community, church, environmental, and health groups, has pushed the Philippines' Food and Drug Administration to take action to regulate the online sales of mercury-containing products, and has been working with local governments to ban such products from markets and beauty shops (EcoWaste Coalition 2011).

Hydroquinone is used as an exfoliant, which can also temporarily lighten the skin. Its adverse effects include irreversible patches of hyperor hypopigmentation and skin cancer, and it is dangerous to use when pregnant (Ladizinski et al. 2011). The Philippines and Indonesia followed the United States in allowing cosmetics with hydroquinone to be on the market as long as the product contains less than $2 \%$ hydroquinone, a concentration that, according to our informants, still causes redness and irritation, and over time, paradoxically, can also cause skin darkening. Moreover, our interlocutors often used exfoliants with concentrations of hydroquinone above $2 \%$, suggesting that the ban is not well implemented.

\section{Marketing Whiteness}

Today's sprawling cosmetics industry promotes skin-whitening products across Asia, and it is hard to find products in pharmacies that don't tout skin-whitening claims. Skin-whitening facial creams, scrubs, capsules, and vaginal washes are advertised online, through mass media, on billboards along busy traffic routes, and, as we saw above, through flash mobs in malls. In Indonesia, such advertisements depict young women with light-skinned faces; while in the Philippines advertising is directed at both young women and young men, targeting not only faces, but also arms, legs, and armpits (see Fig. 5.2).

The markets in the Philippines and Indonesia are saturated with all kinds of products, many made by the multinational companies Unilever, L'Oréal, and Shiseido, the three global market leaders. Unilever sells the Pond's line of products, which offers Indonesia consumers a choice of different kinds of white beauty: pinkish, spotless white, UV protected, and acne blemish lightening. Pond's provides a color-grading bar, which women are encouraged to use to measure their skin-lightening progress. 

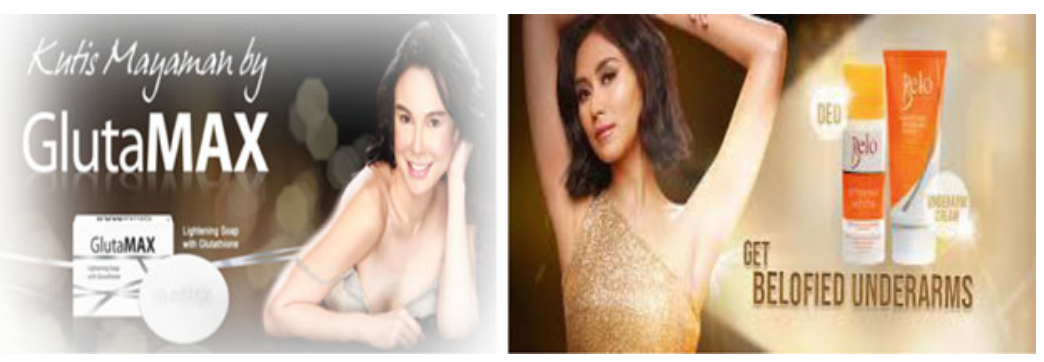

Fig. 5.2 Products sold in the Philippines: Glutamax, with the tagline Kutis Mayaman (Skin of the Rich) and Belo, which is marketed as an armpit whitener (Source Screenshots taken by Anita Hardon, November 2018, the Philippines)

The company is known for its strategic use of social media to promote its products. One campaign by Pond's calls on Indonesian women to do the "half-face challenge" - that is, apply ponds only to half of their faceand share the results on Instagram with the hashtag \#Pondstagram (see Fig. 5.3).

In the Philippines, Pond's TV advertisements are directed toward working women and aired during primetime TV shows. One of the advertisements shows an attractive young professional, with light skin, coming home to her family, who says:

I have to work hard and take care of my face if I want to succeed. So I use only the best. I use Pond's.... I worked hard to achieve my dream [her
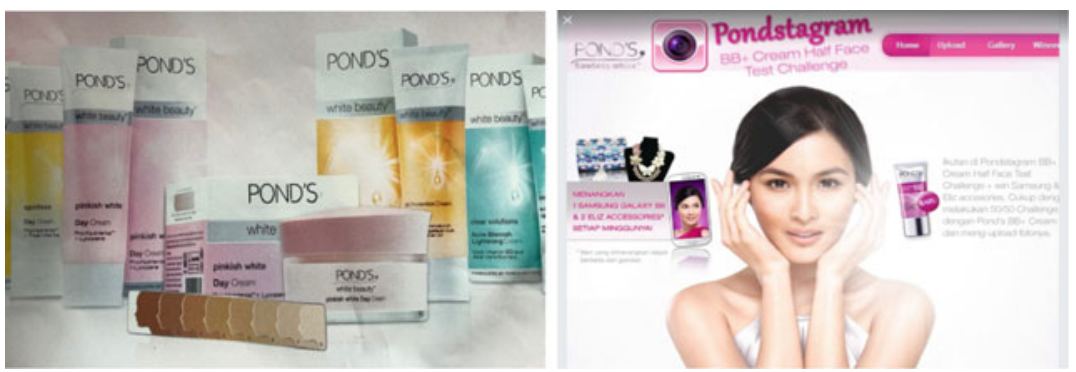

Fig. 5.3 The range of Pond's products sold in Indonesia (Source Photos taken by Anita Hardon, January 2014, Indonesia) 
husband gives her a kiss]. So, I love my life now, because Pond's loves my skin. ${ }^{3}$

Young people in Indonesia and the Philippines use skin-lightening products to increase their capacity to make a living, just as the above Pond's advertisement suggests they should do. Our collaborative fieldwork across sites revealed that skin lightening is an important pragmatic regime for youths who engage in precarious work in the service sector, where many of our informants belong to what Davis (2004) calls the "outcast proletariat," or the urban poor who are "structurally and biologically redundant to global accumulation” (Davis 2004, p 11).

\section{Doing White in Retail Jobs}

Often seen as docile and hardworking, millions of Filipinas have gone abroad to work and have become the human face of the Filipino diaspora. But there is also a significant internal diaspora of young women of various ethnicities who have moved from the rural hinterlands to boomtowns like Cagayan de Oro, a prosperous town on the southern Philippines island of Mindanao. Efenita Taqueban, as part of the ChemicalYouth project, conducted her dissertation fieldwork on skin-whitening practices among youth working in the retail sector in Cagayan do Oro.

City officials have sought to attract Filipino companies and multinational corporations, pointing to Cagayan de Oro's well-educated, friendly, hospitable, and cheap workforce. In recent decades, the growing presence of migrants from nearby municipalities and provinces, lured by the prospects of jobs and education, has transformed the urban landscape. The city is youthful and growing: around 600,000 people currently live there-five times its population of 40 years ago-and half of the population is younger than 25 years old (Philippines Statistics Authority 2013). Taqueban examined retail workers in malls, and observed "that having a 'pleasing personality' — code for a well-groomed face and body, preferably with light, smooth skin-was a requirement to be hired as a sales girl" (Taqueban 2018a, p. 1). Ellie, one of her 
interlocutors, told Taqueban how she spent her money on a bar of Kojic whitening soap, when she was applying to be a sales consultant:

I wanted to look good... The girl selling Kojic was very pretty. Her skin was white and really smooth. I asked her what she was using and she told me she used Kojic. So, I bought the soap. But had to stop using it because it was very expensive. Also, I felt like it was burning my skin. It seems the girl selling the soap was just naturally white. (Taqueban 2018b, p. 39)

Joanna, a human resources manager at a local department store was adamant that she prefers to hire applicants who are light-skinned, explaining to Taqueban that sales girls with a pretty, fair face will sell products better.

Once on the job, human resource managers teach sales girls how to become presentable and pleasing. The use of beauty products becomes a crucial part of their everyday regimens. Felisa, another human resources manager, described how she explained to the girls why they should groom themselves well:

So the client can see that you can take care of your face. You need to promote the product. They'd say you won't be able to sell your product if you don't put on make-up. Even if you're not very pretty, the make-up will help. Use concealers! When you go around, you won't see anyone working in the malls without make-up. Without make-up, you're not attractive. (Taqueban, 2018b, p. 39)

The retail stores in the malls also made use of a make up merit-demerit system. Not putting on make up could result in a demerit, and the girls risked a fine of 50 pesos (approximately US $\$ 1$ ). Company guards inspected them when the girls arrived in the morning, ensuring that the girls were "presentable and ready" before allowing them inside the stores. Supervisors also conducted surprise visits to check the girls' appearance during the day.

Young women had a hard time financing these beauty demands on top of paying rent and buying food, which was more expensive in the 
city. Twenty-year-old Jana, who worked at a clothing store and used unregistered imitation products, explained:

Budget is always an issue if you don't have enough for maintenance. Once you use the product you need to maintain it. People notice and appreciate how you look. If you don't maintain, they'll wonder, "How come you're darker now when you used to be fair?" (Taqueban 2018b, p. 42)

Earning only about US\$100 per month, our interlocutors did what many young people do in the Philippines: buy whitening creams in small quantities, as sachets. "You economize your use, just a little bit every time. I can use one sachet for two days," explained Mel. In local neighborhood sari-sari stores, young people bought small packets of SkinWhite and Pond's (Taqueban 2018b, p. 43). A SkinWhite sachet cost 7 pesos (US\$0.15), while the Pond's ones cost 24-30 pesos (US\$0.50-0.60) (Figs. 5.4 and 5.5).

Young women working in the mall also bought what they referred to as "Class B" products at the local market, imported from China and other Asian countries, which the sales girls claimed were effective whiteners. These are the kind of informal stores where the Zero Mercury Working
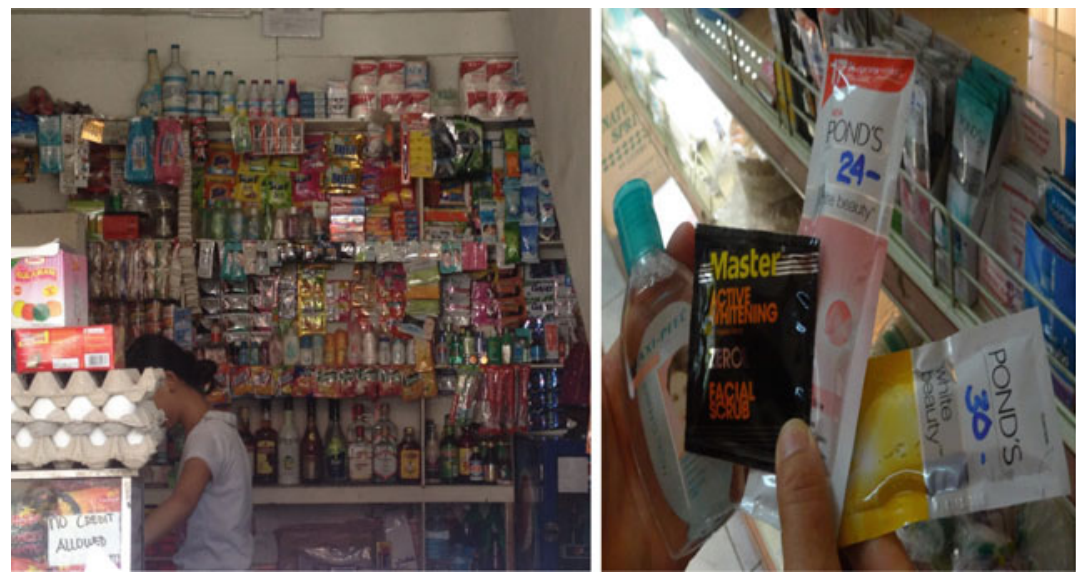

Fig. 5.4 Sachets for sale at sari-sari store (Source Photos taken by Anita Hardon, October 2014, Cagayan de Oro) 


\section{SkinWhite.msinchrompites}

Works in 4 ways all at the same time!

1. WHITENS the skin

2. REDUCES formation of new dark pigments

3. NOURISHES with Vitamins

4. PROTECTS from toxins and UV rays

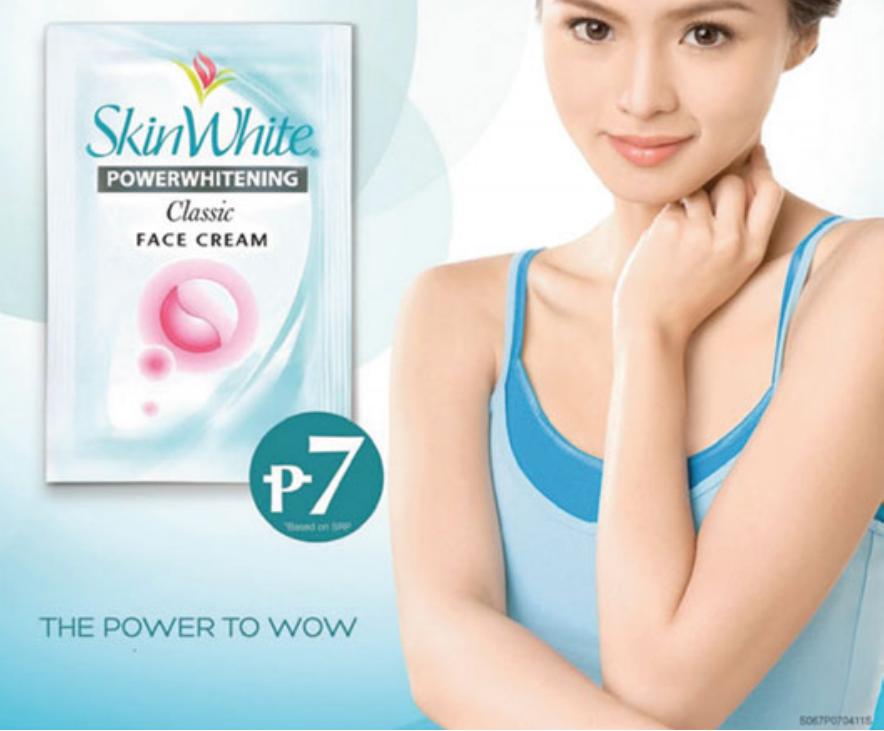

Fig. 5.5 A popular Chinese-Filipino actress models a "power" whitening face cream (Source Screenshot taken by Anita Hardon from The Daily Posh, 2014 https://www.thedailyposh.net/2014/12/skinwhite-launches-bettermecampaign.html)

Group found many creams containing high levels of mercury. Nora, one of the young saleswomen whom Taqueban interviewed, told her that even though "cosmetics made in China feel like they have alcohol and sting," she nevertheless continued to use them: "It's how you know it 
works" (Taqueban 2018b, p. 45). Such Class B products are likely to contain mercury.

On their days off, our interlocutors tended to just use Johnson's Baby Powder to feel clean and to lighten their faces. Alas, even simple powder can have adverse effects on health: in the United States and Canada, concern has arisen about the safety of this product, but these concerns have not yet reached the Philippines. In the United States, the Johnson and Johnson company lost a lawsuit filed by 22 women who claimed that this popular skin product causes ovarian cancer, because it is contaminated by asbestos, a mineral often appearing underground near talc (Rabin and Hsu 2018). The court agreed with the women and awarded them US $\$ 4.69$ billion, one of the biggest personal injury payments ever.

Taqueban's study of skin-lightening practices in the retail sector suggests that the sales girls were under pressure to lighten their skin on daily basis, not only to get jobs but also to keep them. Disciplinary actions by the companies, including fines, motivated them to keep on using this type of product. But because of the costs involved, they bought cheap sachets and Class B products, thereby likely increasing their exposure to mercury. As a result, they risked not only deteriorating their skin but also negatively affecting their overall health. They managed such risks by evaluating the effects of skin-lightening products, and switching brands if they experienced negative effects. But some of the longer term risks, such as skin cancer or damage to renal, immune, or nervous systems, are not immediately apparent. While trying to make a living in this flourishing town, these young women's work may cause them to live more precarious lives.

\section{Doing White in Karaoke Bars}

Karaoke bars are common establishments in towns across Indonesia and the Philippines. They employ women, who keep the customers company if they offer the women a beer (referred to as a "ladies' drink"). The women are generally paid an amount for each offered drink. Where in the retail sector, managers demand that sales girls groom themselves well, 
in the karaoke bars, girls do so on their own to compete with peers for customers.

We conducted research on skin-whitening practices in karaoke bars in coastal towns that are local tourist destinations, in both Indonesia and the Philippines. In Indonesia I did fieldwork with Nurul Ilmi Idrus (see Hardon and Idrus 2015) in a beach destination town in South Sulawesi that we call Isidro, ${ }^{4}$ which attracts young women from across the region in search of better livelihoods. Isidro is a popular destination for funseeking locals; its karaoke bars are located on a ridge in the woods, far from the town center, thus concealing the sale of alcohol which is illegal in the town. The bars cater to men of all ages who come to sing, smoke, drink, and relax with the attractive waitresses. While the bars do not openly provide sexual services (also illegal), the waitresses can make their own informal arrangements to augment their income. Our informants (all female) were employed by the bars, whose owners charged them for both lodging and their necessities, including their skin-lightening products.

Many of our interlocutors in Isidro had migrated from Bali, Papua, Kalimantan, and Toraja. They left behind their families, most of whom were very poor. Some had become pregnant as teenagers, and they had also left their children behind. Having experienced family breakups and economic hardship, many had sought out opportunities to improve their lives. All of them stressed that they wanted to have a steady income to save money for a better future.

Twenty-two-year-old Putri told us that her family couldn't afford to support her high school education, so she took a job at the bar. It was only once she was in Isidro that she realized that the waitresses working in the bar were also providing sexual services. Nevertheless, she did not initially see herself as a sex worker. Early on during her stay in Isidro, she met a man with whom she fell in love with and married. His parents, however, refused her as their daughter-in-law after learning that she was coming from Isidro, an area known for prostitution. Putri's husband then took her back to Isidro and returned to his hometown; she later found out that he was cheating on her and asked him for a divorce. Though she wanted to return to her own home, Putri was afraid that her parents 
wouldn't take her back. When we met, she had been working in Isidro for three years.

Rina was another of our interlocutors. A thin, outwardly cheerful, and talkative young woman of 20, she had graduated from junior high school but did not continue her education, as her father had died and her mother had no money to pay for her studies. Rina said she had been fooled by a friend who offered her a waitress job, and only when she arrived did she too realize that the women working at the bar were expected to also provide sexual services. She recalled feeling trapped, unable to leave because the bar's owner demanded that she pay back the money he had given her friend for recruiting Rina. She also ran up debts buying cosmetics and other products at the store owned by the bar-owner's wife (Fig. 5.6).

During fieldwork, we usually talked to the young women in the afternoons, after they had woken up — many of them worked late, especially if a client hired them for sexual services. When we held a group discussion on the commonly used skin products, our informants stressed that, above

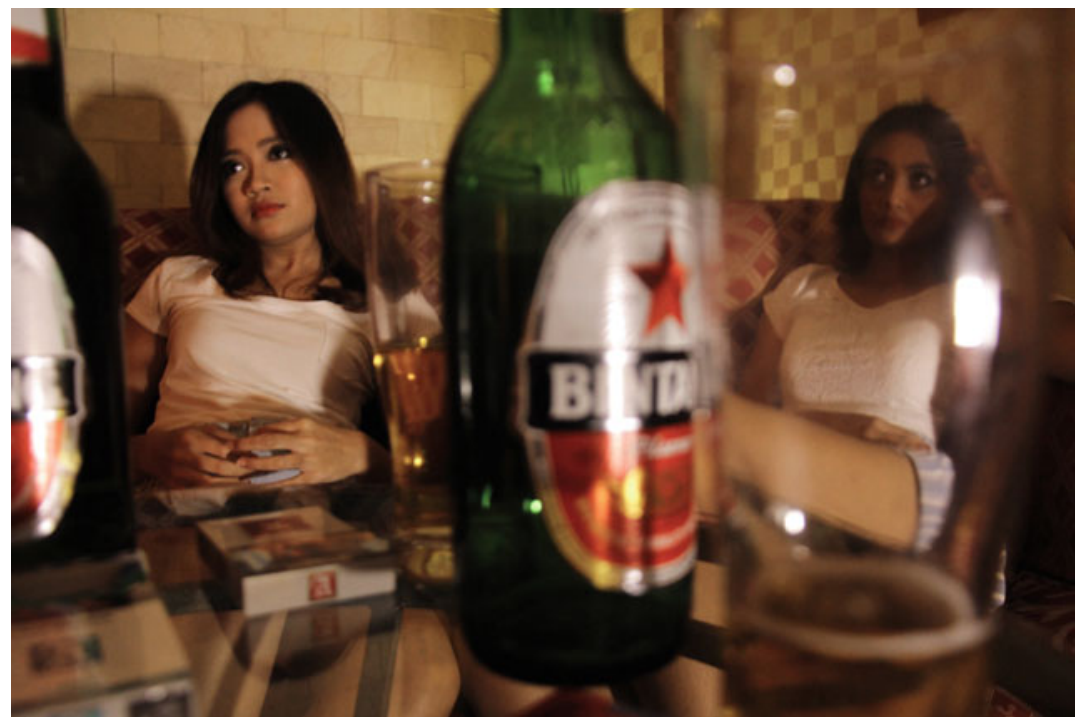

Fig. 5.6 Workers in a karaoke bar with their "ladies' drinks" (Source Photo taken by Sari Damar Rati March 2014, Indonesia) 
all, they desired soft and light-colored skin, and bright, shining faces free of pimples and black spots. This was not only to attract clients; having such well-groomed skin also, they said, increased their chances of finding a husband, a long-term goal held by everyone, including those who were single mothers. The karaoke bar workers recounted to us how they used skin-whitening soaps, powders, foundations, and facial creams on a daily basis. They preferred to use foundation when on the job, because it appears more natural; baby powder, as we found in the Philippines, was used when the girls did not work. When they had a day off, they also used a relatively aggressive exfoliating lotion called RDL Hydroquinone Tretinoin Babyface exfoliant.

Though freely available in stores and markets, RDL is not registered as a cosmetic in Indonesia, nor is it advertised on TV or the radio. Instead, information circulates through RDL Facebook. We heard from sources in Makassar that the products enter Indonesia through the port of Manado, which is very close to the Philippines island of Mindanao. Small trading vessels carry Philippine products to Indonesia, and then transport batik sarongs, clothes, and spices back. The women we interviewed asserted that RDL works by peeling the outer layer of skin; the treatment lasts for three consecutive days, and so they scheduled it on days off and when there were few customers. The wife of the bar owner sold our informants RDL for 15,000 rupiah (a little less than US\$2), while their total earnings for bar work were usually about US\$30. This was not enough to pay for their daily needs, and many like Rina had debt, which pushed them to go out with clients and earn some more money as sex workers (Table 5.1).

The declaration of contents that we found on the packages suggests that the products used in the karaoke bars of Isidro have a $4 \%$ hydroquinone concentration, making them illegal by Indonesian regulatory standards for cosmetics. Notice that this package of RDL does not declare mercury contents—a substance found by the Zero Mercury Working Group in the night cream version of RDL (a product that also did not declare its mercury content).

While our informants in the karaoke bars of Isidro complained that the exfoliating products felt pedas (hot) on their skin, they suggested this was a sign of their efficacy. When we opened a bottle of RDL, it smelled more like a strong chemical stain remover than a skin cream. 
Table 5.1 RDL product information, copied from the package, October 2016

\begin{tabular}{|c|c|c|c|}
\hline Brand & Manufacturer & Content & Product information \\
\hline $\begin{array}{l}\text { RDL } \\
\text { hydroquinone } \\
\text { tretinoin } \\
\text { Babyface } \\
\text { solution }\end{array}$ & $\begin{array}{l}\text { RDL } \\
\text { Pharmaceutical } \\
\text { Laboratory, } \\
\text { Davao, } \\
\text { Philippines }\end{array}$ & $\begin{array}{l}\text { Each } \mathrm{ml} \text { contains } \\
\text { a } 40 \mathrm{mcg} \\
\text { hydroquinone } \\
\text { and } 20 \mathrm{mcg} \\
\text { tretinoin }\end{array}$ & $\begin{array}{l}\text { - Anti-acne/Keratolytic } \\
\text { depigmenting agent } \\
\text { - For topical treatment } \\
\text { of acne vulgaris and } \\
\text { pathological } \\
\text { hyperpigmentation } \\
\text { - Use once or twice a } \\
\text { day } \\
\text { - Warning: should not } \\
\text { be used for longer } \\
\text { than } 2 \text { months; do } \\
\text { not apply to broken } \\
\text { skin; do not use to } \\
\text { treat more than } 10 \% \\
\text { of body surface; } \\
\text { should not be used } \\
\text { by pregnant women } \\
\text { - Precaution: avoid } \\
\text { excessive exposure to } \\
\text { sunlight }\end{array}$ \\
\hline
\end{tabular}

Most women nevertheless endured weekly treatments. In our focus group with the bar workers in Isidro, Neni admitted: "It feels so hot, it makes me cry." After applying the exfoliating liquid, the young women sat in front of a fan to cool their faces. Only two young women we spoke with refrained from using skin-peeling products, stating that they were bad for their skin and that the products were not cocok (suitable) for them. They cultivated an oriental identity, which they said some Korean businessmen found attractive (Hardon and Idrus 2015).

Skin lightening was also a key chemical practice for our interlocutors in the karaoke bars in Puerto Princesa, a rapidly growing tourist destination on the island of Palawan, the Philippines. Unlike in Isidro, the bars are legal in this city, and the municipal health department checks the workers regularly to make sure they don't have sexually transmitted diseases or HIV. The bars are along the main roads in the town, welcoming the many Filipino tourists who visit this town annually, and downtown near the tourist market. Every year in November business is 
good, because American soldiers visit Puerto Princesa after completing military practice with their Filipino peers.

Alvie Bergado Timbancaya and I visited two karaoke bars regularly: one relatively expensive club, which also caters to foreigners, and one lower-end bar with mainly local Filipino clients (see Bergado Timbancaya 2017). We went early in the evening, when the young women were hanging around and waiting for clients, and talked with them about their life trajectories, family, income, and investments in beauty. We bought them ladies' drinks, which meant that they could join us and talk, and we watched them parade around on the bar's catwalk and do pole-dancing to entertain their clients.

At the low-end bar, the young women earned money when a customer bought them a drink (70 Philippines pesos per glass of beer, or about US\$1.40), just as their peers in Isidro did. They sang and drank with their customers, and they told us that fair-skinned young women get picked first by clients, something we also observed firsthand.

Kaye, 22 years old at the time, had been working at the low-end bar for more than eight months. She did not finish high school because she got pregnant when she was a teenager. When we met her, she had two sons, still too young for school, who stayed with her parents in a village in Puerto Princesa. Kaye visited them twice a week. She started working in the karaoke bars after her husband died in a traffic accident. She initially applied to be a waitress, but realized she could earn more for her family by working in karaoke bars. On average she earned 140 pesos a night, and more (around 500 pesos) if a customer hired her for a few hours and paid a fee to her manager. Kaye regularly used Silka Papaya soap, which she said was hiyang with her skin, to lighten her complexion. She also used Yoko Pearl Cream twice a day to lighten and moisturize her skin after washing it with Silka. Kaye explained that her skin is sensitive, so she carefully tried out products and used only those that didn't irritate her skin. Her coworker Mhay, a 20-year-old, used products that were less gentle, including Maxi-Peel body scrub (which contains hydroquinone $2 \%$, just at the threshold level, hence not banned) on her body when she took a bath, twice a day. After bathing she used Pond's whitening facial scrub on her face, and then Eskinol lightening toner to remove cosmetic 
residue from the night before, followed by Pond's whitening facial cream. Pond's is a relatively expensive brand.

The Filipino company Splash promotes hydroquinone-containing Maxi-Peel as follows on its Facebook site:

Launched in 2001, Maxi-Peel is the leader in the exfoliants category, with its complete range of skin care products that aim to help women achieve fairer, smoother, and beautifully renewed skin. What makes MaxiPeel work? Over the years, its breakthrough and unique formulation of Tretinoin and Hydroquinone, which is used to treat and prevent mild to severe pimples, was able to build its credibility and loyalty with its consumers due to its effectiveness. Only Maxi-Peel provides potent exfoliation technology that removes blemishes, smoothens and lightens in just two weeks. (Maxi-Peel Skin Care 2020)

Ella, another interlocutor who was 23 years old when we met, worked in the high-end bar, where she could earn a slightly better income than in the lower-end one. Ella was born in Laguna, on the island of Luzon, and had been recruited in her home village by an agent who brought her to Puerto Princesa to work in the karaoke bar. She was single and did not have children. She lived above the bar, and received 50 pesos per day as food allowance from her manager. She explained to us that she earned 100 pesos for every ladies drink, and could earn more-as much as 1500 pesos - if a customer took her out. In total, customers paid the bar 3500 pesos to hire a young woman for a few hours, of which 2000 was given to the manager as a fee.

Like Mhay and Kaye, Ella aspired to have fairer skin and considered girls with lighter skin more beautiful, but she had trouble achieving it because her skin was quite dark. She was grateful to learn that some foreigners, including Europeans and Koreans, were attracted to her "oriental" looks. Still, she tried to become more attractive by making her breasts bigger with hormonal pills, but stopped doing this because she couldn't afford to take the pills every day. Instead, she invested in rebonding her hair, whenever she had a client who took her out. Rebonding made her hair silky and noticeable when she walked the pretend catwalk in the club. The bar invited Ella and the young women 
to do so a couple of times per evening, to allow clients to select which women they wanted to offer a drink and/or take out.

Mercury, hydroquinone, and Johnson's Baby Powder (possibly contaminated by asbestos) were some of the chemicals contained in the cheap products used regularly by hospitality workers in our field sites in the Philippines and Indonesia. They used these products to have lighter skin in order to attract clients, but this was a double-edged sword: if their skin deteriorated due to these products, they were likely to lose their jobs. The painful reality as that they were unaware of the risks, and when skin damage occurred it was too late.

\section{Keeping Up with the Times}

The Philippines has witnessed a feminization of its labor force, along with an expanding service sector (Pingol 2001). Young women in the Philippines are generally better educated than men and they are more likely to be employed in the booming service sector. Young men who grow up to be providers for their families often have adjusted their aspirations (Eder 2006). If they wanted to compete with women for service sector jobs, having whiter skin could increase their chances of being selected. It could also be an advantage in dating, as lighter skin was associated with wealth and upward mobility.

Changing representations of masculinity in popular youth culture have also affected male skin-lightening practices. Non-heteronormative men are popular presenters and actors on Filipino TV shows and series, and South Korean TV dramas show androgynous men portraying feminine beauty and tenderness. These cultural representations have paved the way for men to care more about their skin and appearance (Lasco and Hardon 2019). According to industry reports, skin-lightening products for men have achieved "robust penetration" (Global Industry Analysis 2018). The advertisements below reflect the changing times (Fig. 5.7).

Glutamax is heavily advertised on billboards and in the mass media for its whitening effects, and glutathione, its key ingredient, is registered in the Philippines as a food supplement. It is an antioxidant that plays a role in a range of cellular processes in humans. It can convert melanin to 

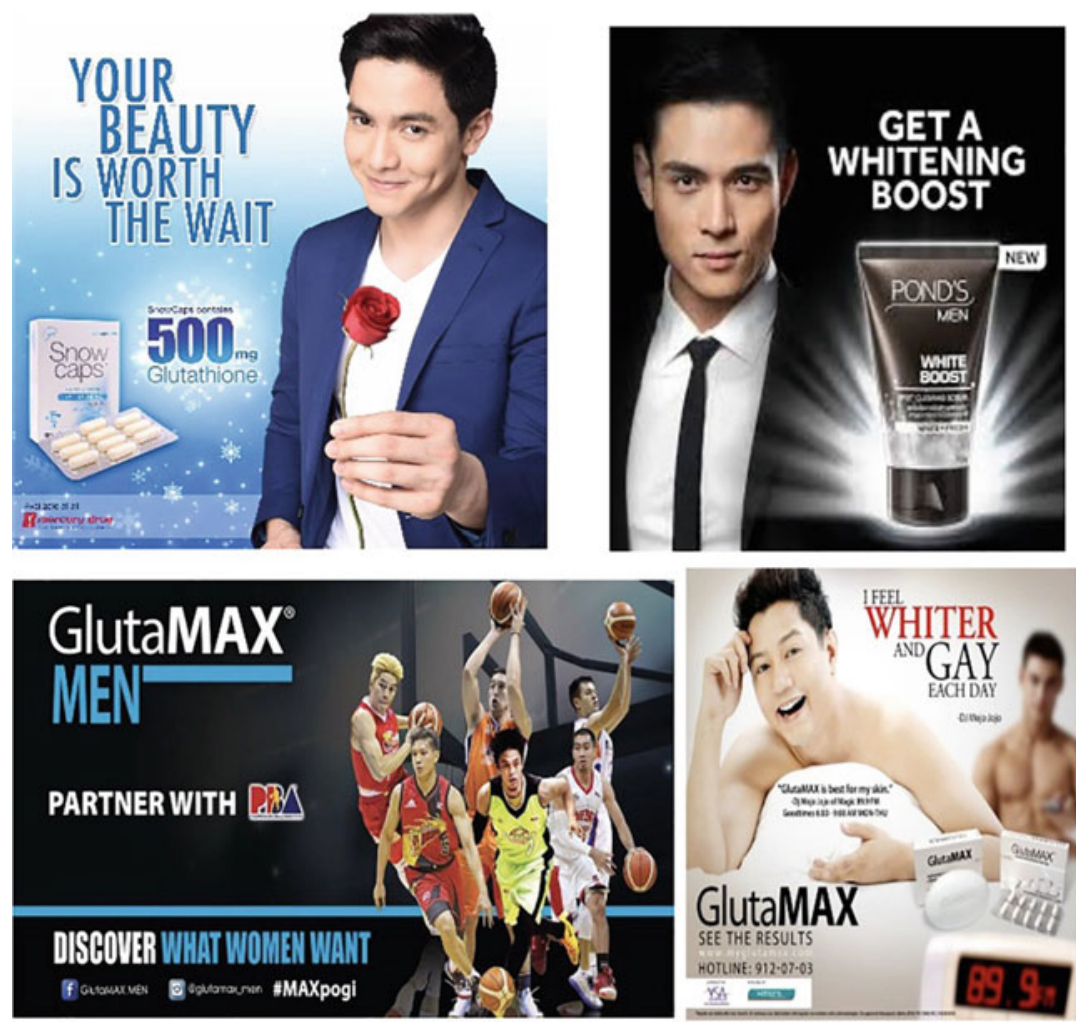

Fig. 5.7 Advertisements of whitening products for Filipino men. Note how GlutaMAX targets both gay men and apparently heterosexual sportsmen, while Pond's Men appeals to men who aspire to join the middle class (Source Photo taken from Lasco and Hardon [2019])

a lighter color, which is how it changes skin tones. Toward the end of our fieldwork in 2018 we noticed new clinics offering glutathione injections and drips. The Philippines Food and Drug Authority (PFDA) was alerted about this new trend and issued a statement in 2019 to the general public, stating that there had been no published clinical trials to evaluate the use of injectable glutathione for skin lightening, and that the PFDA had therefore not approved any injectable product for this indication. The statement also warned that side effects from injectable glutathione for skin lightening include toxic effects on the liver, kidneys, and nervous 
system; and that glutathione affects the production of melanin, which raises concerns about the long-term risk of skin cancer (PFDA 2019).

Advertising strategies for skin-whitening creams and washes feed into and reinforce these new aspirations among young men to lighten their skin. They present the use of skin whiteners as "solutions to gender and class-based 'status problems"' (Atkinson 2007, p. 170). The ad for Belo Men Whitening Body Bar- "10\% lighter, 100\% more social: a little whitening makes a big difference"-for example, feeds into worries about finding a job and promises its users upward social mobility (Lasco and Hardon 2019), see Fig. 5.8.

Very popular, as well, were masculine facial washes, which promise deep cleaning, acne control, and "active whitening." These facial washes are sold in black sachets, in small neighborhood stores, making them accessible to men with little money. Capsules and injections containing glutathione are more upmarket forms of whitening. The advertisements and packages of skin-whitening products for men both reflect and reinforce prevailing gender identities and skin ideals, while also indexing that light skin is associated with good jobs (Lasco and Hardon 2019). We noticed that in Manila, the male students from high-income households
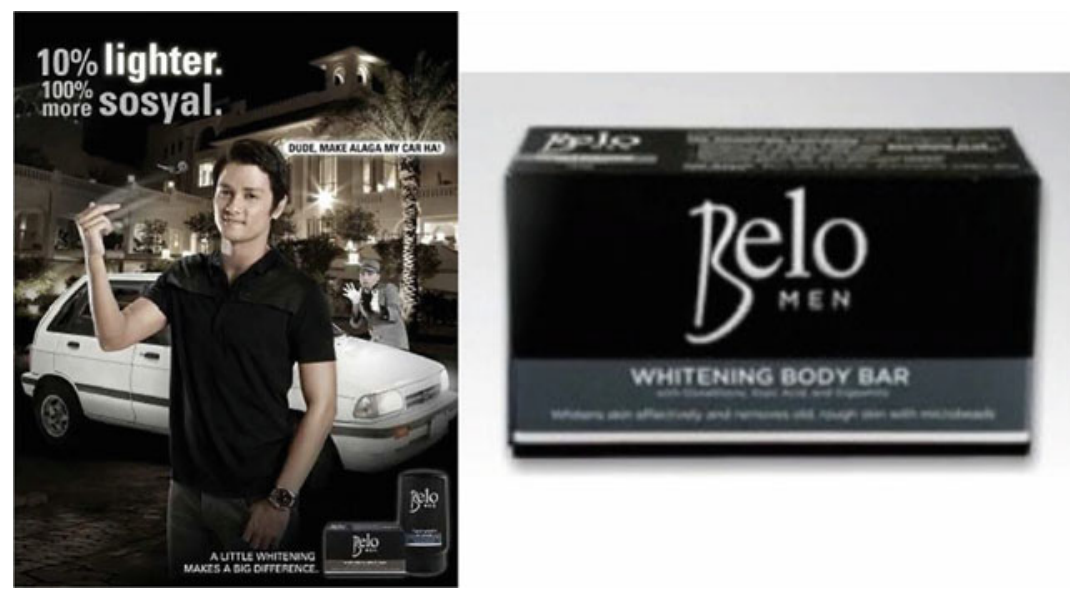

Fig. 5.8 "10\% lighter and $100 \%$ more social," with Belo Men Whitening Body Bar (Source Photo by Gideon Lasco, September 2018, the Philippines) 
did not see a need to lighten their skin. They expected to find a job easily or knew they could rely on their families, but those with a poorer starting position in life were reluctantly experimenting with ways to lighten their skin.

Take, for example, this exchange between Karl, a 17-year-old high school student, and Gideon Lasco, who conducted ethnographic research in Quezon City:

Karl: Some jobs won't accept you if you are dark-skinned.

Gideon: What kind of jobs?

Karl: Many-they just don't accept dark-skinned applicants.

Gideon: So, you know anyone who wasn't accepted because he was dark?

Karl: Well, they wouldn't say that they rejected you because of the color of your skin, they just won't contact you again, and they will prefer the others. They will just tell you that the position has been taken and they will call you back [if they still want you] (Lasco and Hardon 2019, pp. 9-10).

Cyrus, a 19-year-old living in university housing, told us about his peers: "They do [skin-lightening practices] very late at night, around 1 to 2 AM, when no one's watching." He continued: "In the common shower room, I see all kinds of whitening products like Kojic Acid soap, papaya soaps, glutathione creams, even lotions and face-masks" (Lasco and Hardon 2019, p. 1).

\section{Celebrating Skin Diversity}

To counter the culture cycle through which the notion that having white skin equals intelligence, beauty, and wealth is perpetuated, we sought out ways to celebrate skin diversity. We noted counter-discourses emerging in popular culture, including magazines that showed celebrities seeking to darker skin by tanning and showing off their bikini lines. And they are present in the lyrics of a Filipina American rapper named Ruby Ibarra, who migrated to the United States with her family when she was still a child in 1991. Her lyrics reflect on her mixed identity, experiences, and 
struggles, and tells stories of racial discrimination and colorism, as well as her pride in being a woman. For her album $U_{s}$, Ibarra gathered a group of female artists, who were proud of their roots, and declared their unique heritage as they transitioned through life-stages and lived in different places (Salanga 2018). In the title song, Ibarra calls on her Filipino peers to resist hegemony: "Island woman rise, walang makakatigil [nothing can stop you]. Brown, brown woman, rise, alamin ang yung ugat [know your roots]."

To contribute to this emerging trend, the youth ethnographers worked with art students and resident artists at the University of the Philippines to produce a set of multimedia translations. One of these translations was the Kataw(h)an exhibit, the name of which combines the words for "body" (katawan) and "stories" (katawhan), and which was intended to celebrate body narratives and skin tone diversity in the Philippines (UP Diliman Information Office 2018). At the entrance to the exhibit was a gallery called "Subconscious Substance." It had shelves of popular skin products (as in a small grocery shop), which, instead of showing their brands, featured the back of the products, showing their long lists of chemical contents. Visitors to the exhibit recognized their brands from the shape and color or the containers, but were drawn to inspect the chemical lists, which many had never previously scrutinized (Fig. 5.9).

The gallery was explained in a panel with the following text that was written by the team of arts student which designed the gallery:

From the visible areas of the body to its hidden parts, we consume all substances to enhance our appearance, improve our health and ultimately feel good about ourselves. We apply, rub, spray and even ingest these chemicals in order to maintain what we believe is a good sense of hygiene and to satisfy the criteria of our concept of the ideal body. We consume most of the products that we patronize due to the influence of peers and the testimonies of people who have undergone the process of maintaining their look and their lives. We place our faith the in the products with carefully phrased taglines, sometimes even disregarding the chemicals that we put on our hair, face, genitals, skin and even let flow in our bloodstream. This gallery is a collection of the products used by actual people who believe in these products' providence in realizing and preserving their notions of beauty. (UP Diliman Information Office 2018) 

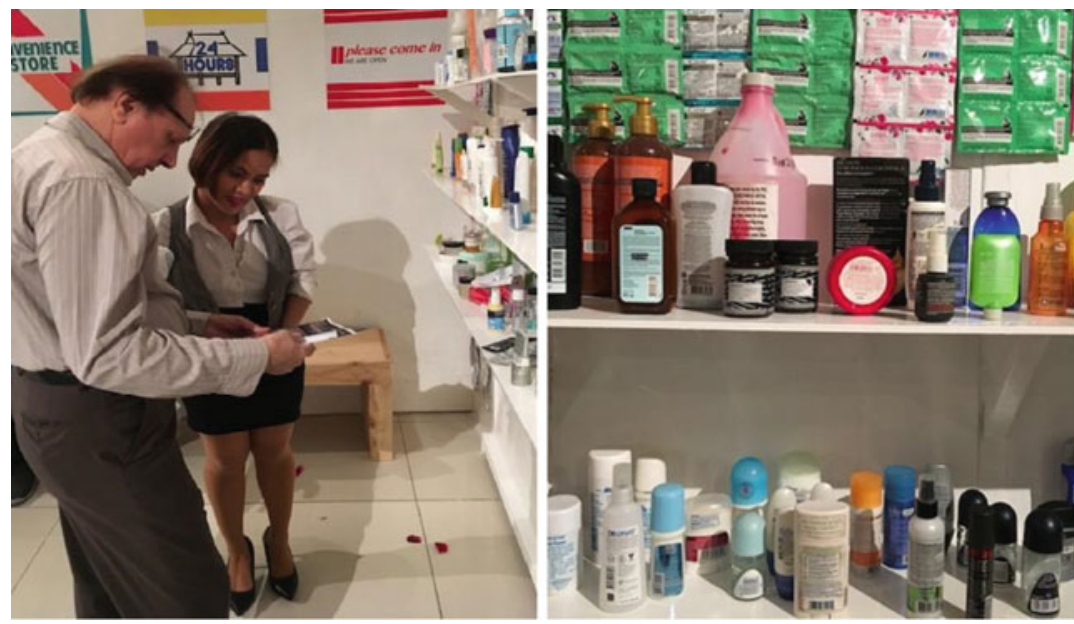

Fig. 5.9 Picture of one of the panels in the Kata(h)wan exhibit, where a makeshift pharmacy presented skin-whitening products with their lists of chemical contents facing customers, rather than the brand names (Source Photos by Anita Hardon, January 2018, the Philippines)

Another visual arts project, which also culminated in an exhibit at the University of the Philippines, was designed to celebrate Filipino heritage and cultural diversity. The multidisciplinary project became a collaboration among geneticists, social scientists, and artists, who together explored what it is to be Filipino in the contemporary Philippines. An animated video in the Stasis and Mobility exhibit, designed by Christian Paolo Bautista, told the story of early Austronesians whose seafaring technology brought them to and from the archipelago as they moved throughout the Pacific, centering the Philippines as an important hub in exchange of goods and knowledge (Fig. 5.10).

The exhibit included an installation by visual artist Aidan Blaise Zamora, entitled the "Citizen's Gallery" which used several hundred found or directly sourced family photos from University of the Philippines students. The photos were strategically hung to represent the shape of a sailing ship (mirroring the sailboat in the image below), yet viewed up close, distinctive facial features of people and families illustrated the diversity of a nation whose citizens have mixed ancestry. 


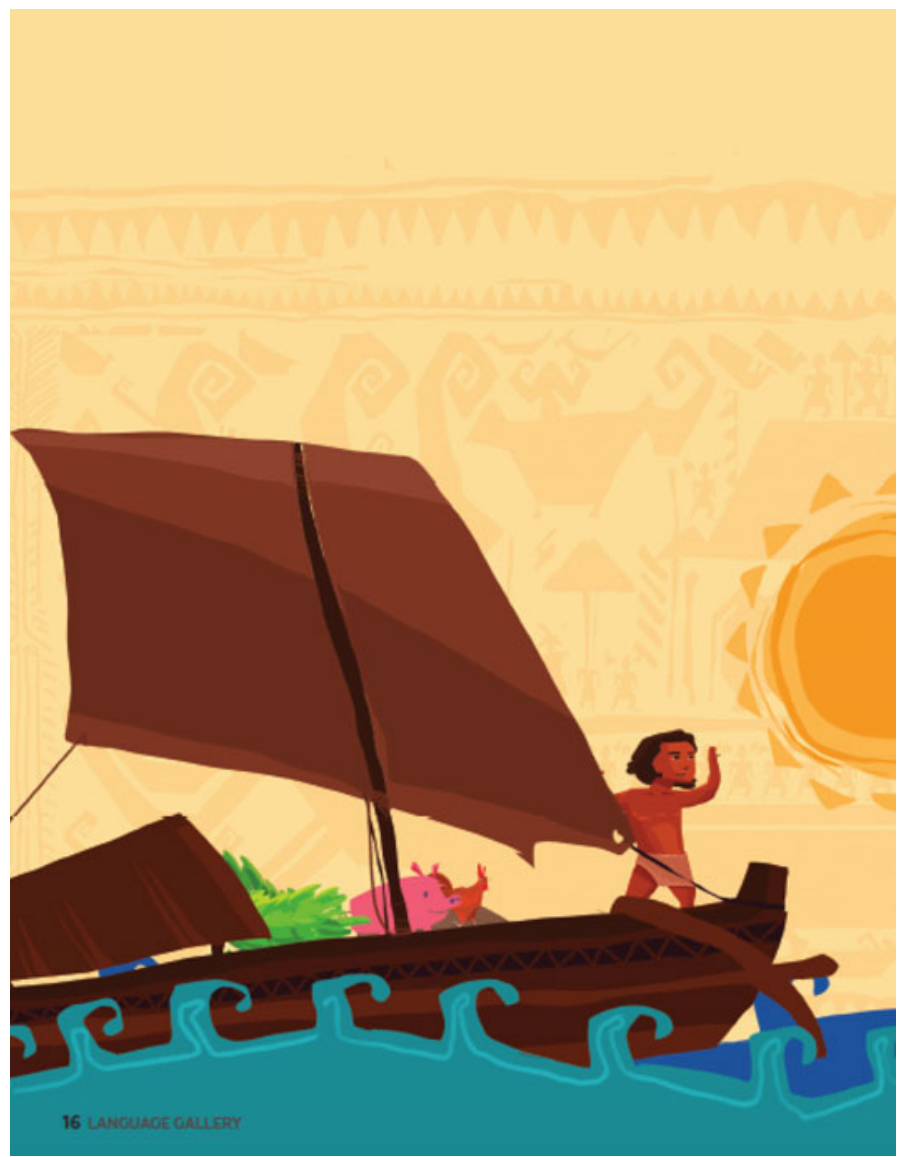

Fig. 5.10 Peopling of the Philippines, reproduced with permission from Stasis and Mobility exhibit "Nasa Dugo Natin 'Yan?!" (Tiatco 2018)

The contemporary migratory flows of people through the Philippines has added several sociocultural identifying markers to the story of the archipelago's peopling: "mestiza, mestisaje and peninsulares during the Spanish colonial era; Amerasian, amboy, and tisoy during the American colonial period; and the current waves of Fil-Am, Fil-European, Kopinoy, and Japinoy" (Fig. 5.11). 

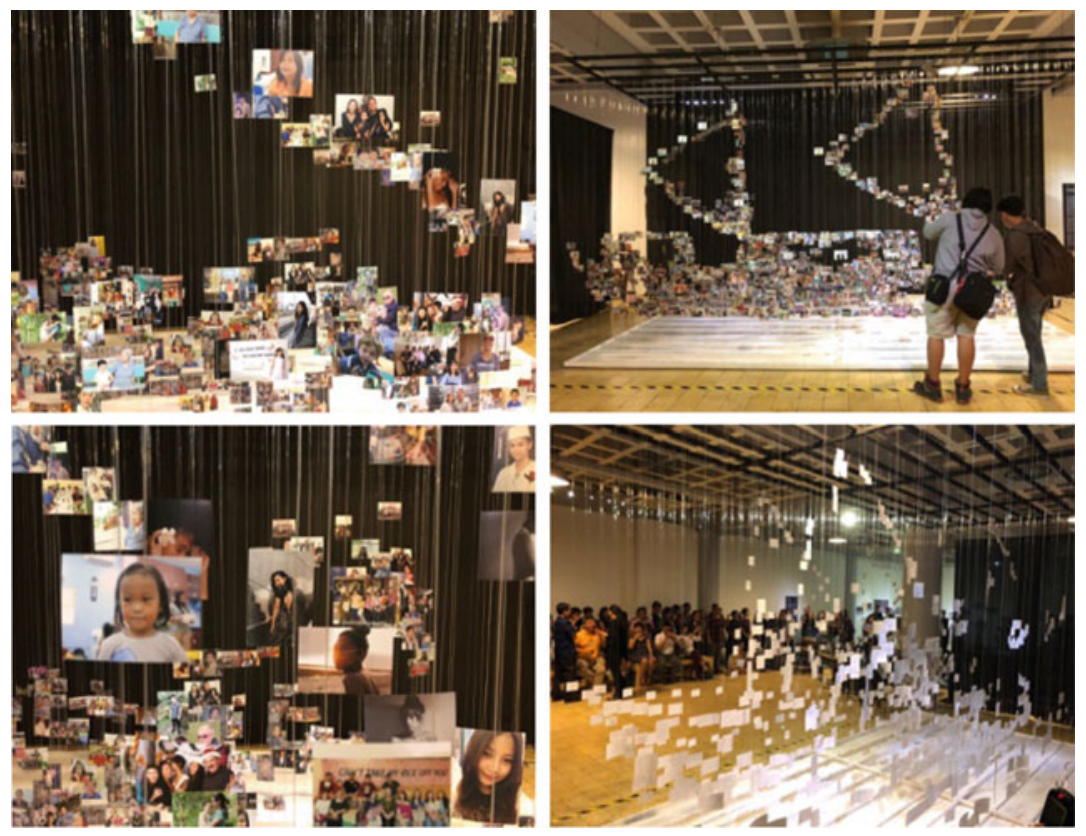

Fig. 5.11 Citizens Gallery, photo installation from Stasis and Mobility exhibit (Source Photos taken by Andie Thompson, October 2018, the Philippines)

Finally, we worked with young filmmakers to produce two minidocumentaries (Fair and Flawless and Natural Lang) that examined skinwhitening practices in Manila, and contrasted these with the embrace of brown skin in a surfing community in the south of the Philippines. Natural Lang shows female surfers, who did not lighten their skin, because doing so would make surfing impossible: they need melanin to protect them from the sun. ChemicalYouth presented their point of view-as women who are proud to be brown-in a 15-minute documentary accessible on Vimeo (Op den Kamp and Sanchez 2014) (Fig. 5.12). 


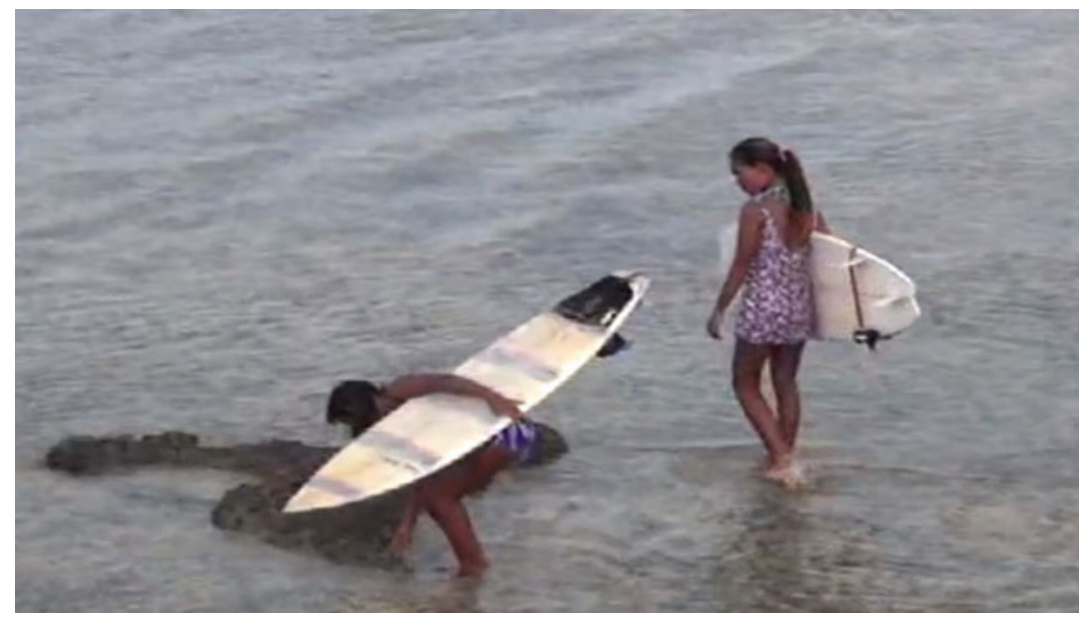

Fig. 5.12 Proud to be brown: Surfer women in Siargao Island, Philippines (Source Screenshot by Anita Hardon January, 2018 from Natural Lang [minidocumentary] by Op den Kamp and Sanchez [2014])

\section{In Conclusion}

This chapter examined the interpersonal dynamics and institutional policies that perpetuate colorism in the service sector, attending to the highly material work undertaken by service sector workers in order to "do" the white skin that their employers expect of them. Gender shapes these practices, as we saw with the young men in the Philippines who are competing with women for service sector jobs, which has led them to embrace skin whiteners just as their female peers do. Having light skin takes on a specific value in interactions in the service sector, where lighter skin can attract clients and thus have economic value. We show how having light skin does increase one's chance of getting a job in malls in the Philippines; this form of institutional colorism contributes to the precariousness of youth people who are not born with light skin. But the discriminatory work policies, and the selling and marketing of skinwhitening products by personal care companies are not just harmful because they perpetuate a culture cycle (Markus and Conner 2013) that 
privileges having white skin: they are also harmful because many skinwhitening products contain toxic chemicals, which can disfigure those who use them.

The production of the multimedia exhibits and mini-documentary created experimental spaces in which to resist hegemonic notions that equate white skin with intelligence, beauty, and wealth; in the process, values attached to skin colors are re-imagined. But the impact of these cultural expressions is limited in countries with retail markets that are saturated with skin-whitening creams, scrubs, and soaps, and media landscapes that amplify the idea that fair skin is better. To counter the culture cycle that perpetuates white privilege, we believe that personal care companies should stop producing and marketing skin-whitening creams, scrubs, soaps, and washes; governments should regulate the colorist advertising of such products; and occupational health policies should impose sanctions against colorist hiring and human resource strategies. Perhaps a global treaty, similar to the one adopted for tobacco, is needed. The harms caused by skin-whitening products are symbolic and social, as well as economic and biomedical. They channel youths' scarce resources away from basic needs to unnecessary cosmetic practices that require multiple products and applications. They also cause harm because they reinforce colorism, which disadvantages youth with darker skin. Moreover, they push young people into using products that can cause harm, further increasing inequalities.

While finalizing this chapter for publication amid the June 2020 global protests against racial injustice, I was sent a press release in which Unilever (the manufacturer of Pond's skin-lightening cream mentioned in this chapter) announced that it will remove the words "fair/fairness," "white/whitening," and "light/lightening" from its products, packaging, and communications. Sunny Jain, president of Beauty \& Personal Care, says this change is being made because the company is "fully committed to having a global portfolio of skin care brands that is inclusive and cares for all skin tones" (Unilever 2020, p. 1). Activists, however, insist that rebranding products are just a start. Much more is needed to address the mental and emotional damage done by colorism (Berger 2020). 


\section{ChemicalYouth Ethnographers}

Efenita (nickname Mai) Taqueban is an Assistant Professor in Social Anthropology at the University of the Philippines. She teaches social anthropology, with interests in gender, global political economy, and social suffering. Her master's thesis drew from the stories of induced abortion by mothers from an urban poor community in Manila. She received her Ph.D. from the University of Amsterdam, where she studied young women and their cosmetic and skin-whitening practices in a swiftly urbanizing southern Philippine boomtown. She also serves as a legal advocate (Fig. 5.13).

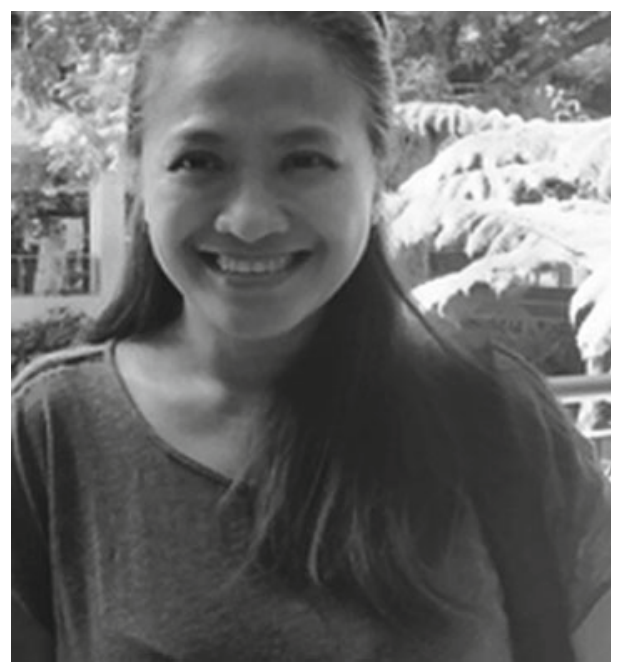

Fig. 5.13 Efenita Taqueban 
Gideon Lasco is a physician and medical anthropologist. He obtained his Ph.D. from the University of Amsterdam as a member of the ChemicalYouth project and his M.D. from the University of the Philippines, where he currently teaches anthropology. His research includes the chemical practices of young people, the meanings of human height, the politics of health care, and the lived realities of the Philippine "drug war." A Palanca-winning essayist, he maintains a weekly column in the Philippine Daily Inquirer, where he writes about health, culture, and society (Fig. 5.14).

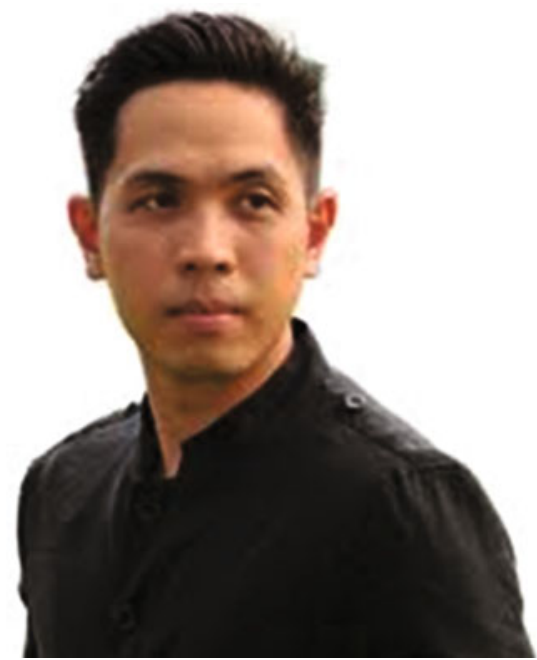

Fig. $\mathbf{5 . 1 4}$ Gideon Lasco

Alvie Bergado Timbancaya was a researcher for the ChemicalYouth project at the Palawan Studies Center at Palawan State University and conducted fieldwork on gender identities and chemical use among sex workers and service sector workers in the Philippines.

\section{Notes}

1. Biocapital has been used in anthropological literature to describe how value is generated through the insertion of biological materials, such as stem cells and patented genes, into capitalist modes of production. For example 
Rajan (2006) and Franklin (2003) argue that biocapital is accumulated by powerful actors in the global economy, including biochemical industries and bioresearch labs.

2. The Minamata Convention is an international treaty designed to prevent emissions of mercury into the environment, and to prevent people from suffering its toxic effects. This convention was approved by delegates representing close to 140 countries in October 2013 and entered into force in 2017. It is named after the Japanese city Minamata, which experienced a devastating incident of mercury poisoning.

3. The text of this advertisement was transcribed from a TV advertisement. The video of the advertisement is included in the mini-documentary Natural Lang (see Op den Kamp and Sanchez 2014). The advertisement was also aired in July 2009 in a NPR podcast "Skin whitening a global practice" https://www.npr.org/templates/story/story.php?storyId=106 419771.

4. This is a fictitious name, to protect our informants who were engaged in activities that were illegal according to local Islamic laws.

\section{References}

Abrera, M. B. (2009). Seclusion and veiling of women: A historical and cultural approach. Philippine Social Sciences Review, 60(1), 34-56.

Atkinson, M. (2007). Playing with fire: Masculinity, health, and sports supplements. Sociology of Sport Journal, 24(2), 165-186. https://doi.org/10.1123/ ssj.24.2.165.

Bergado Timbancaya, A. (2017). The use of chemical products by market vendors in Puerto Princesa, Palawan. In A. Hardon \& M. L. Tan (Eds.), Modernizing Frontier: Chemical transformations of young people's minds and bodies in Puerto Princesa (pp. 81-88). Quezon City: University of the Philippines Diliman. https://pure.uva.nl/ws/files/47815148/Modernizing_Fronti ers.pdf.

Berger, M. (2020). After protests, a Unilever skin cream popular in India will no longer promote a 'Fair \& Lovely' look. Washington Post. https://www. washingtonpost.com/world/2020/06/25/after-protests-unilever-skin-creampopular-india-will-no-longer-promote-fair-lovely-look/. Accessed June 25, 2020 . 
Chua, B.-H. (2000). Where got Japanese influence in Singapore! In J. Ben-Ari \& E. Clammer (Eds.), Japan in Singapore: Cultural Occurrences and cultural flows (pp. 133-149). Surrey: Curzon Press.

Davis, M. (2004). The urbanization of empire: Megacities and the laws of chaos. Social Text, 22(4), 9-15. https://doi.org/10.1215/01642472-22-4_ 81-9.

Deacon, G. (2011). There's lead in your lipstick: Toxins in our everyday body care and how to avoid them. Toronto: Penguin Canada.

EcoWaste Coalition. (2011). EcoWaste coalition finds mercury in skin whitening products, pushes crack down on dangerous cosmetics. EcoWaste Coalition. http://www.ecowastecoalition.org/ecowaste-coalition-findsmercury-in/. Accessed January 20, 2020.

Eder, J. F. (2006). Gender relations and household economic planning in the rural Philippines. Journal of Southeast Asian Studies, 37(3), 397-413. https://doi.org/10.1017/S0022463406000701.

Ellis, P. (dir.). (2019). Toxic beauty. Canada: Kew Media.

European Environmental Bureau. (2018). Zero mercury working group: Mercury-added skin-lightening creams: Available, inexpensive and toxic. European Environmental Bureau. https://eeb.org/library/mercury-added-skin-lig htening-creams-available-inexpensive-and-toxic/. Accessed on January 20, 2020.

Farrugia, D. (2018). Youthfulness and immaterial labour in the new economy. The Sociological Review, 66(3), 511-526. https://doi.org/10.1177/003802 6117731657.

Franklin, S. (2003). Ethical biocapital: New strategies of cell culture. In S. Franklin \& M. Lock (Eds.), Remaking life and death: Toward an anthropology of the biosciences (pp. 97-128). Santa Fe, NM: School for Advanced Research Press.

Glenn, E. N. (2008). Yearning for lightness: Transnational circuits in the marketing and consumption of skin lighteners. Gender and Society, 22(3), 281-302. https://doi.org/10.1177/0891243208316089.

Global Industry Analysis. (2018). Skin lighteners. Market analysis: Trends and forecasts. Global Industry Analysis. https://www.strategyr.com/MCP6140.asp. Accessed on January 3, 2020.

Hardon, A., \& Idrus, I. (2015). Chemicals, biocapital and the everyday lives of sex workers and waitresses in South Sulawesi. In L. R. Bennett \& S. G. Davies (Eds.), Sex and sexualities in contemporary Indonesia: Sexual politics, health, diversity and representations (pp. 129-147). Oxfordshire: Routledge UK. 
Hardt, M., \& Negri, A. (2000). Empire. Cambridge, MA: Harvard University Press.

Hochschild, A. R. (1983). The managed heart commercialization of human feeling. Berkeley: University of California Press.

Ladizinski, B., Mistry, N., \& Kundu, R. V. (2011). Widespread use of toxic skin lightening compounds: Medical and psychosocial aspects. Dermatologic Clinics, 29(1), 111-123. https://doi.org/10.1016/j.det.2010.08.010.

Lan, P. (2001). The body as a contested terrain for labor control: Cosmetics retailers in department stores and direct selling. In R. Baldoz, C. Koeber, \& P. Kraft (Eds.), The critical study of work: Labor, technology, and global production (pp. 83-105). Philadelphia: Temple University Press.

Lasco, G., \& Hardon, A. P. (2019). Keeping up with the times: Skinlightening practices among young men in the Philippines. Culture, Health and Sexuality, 1-16. https://doi.org/10.1080/13691058.2019.1671495.

Leidner, R. (1999). Emotional labor in service work. The ANNALS of the American Academy of Political and Social Science, 561(1), 81-95. https://doi.org/ 10.1177/000271629956100106.

Li, E. P. H., Min, H. J., Belk, R. W., Kimura, J., \& Bahl, S. (2008). Skin lightening and beauty in four Asian cultures. Advances in Consumer Research, 35(January), 444-449.

Markus, H., \& Conner, A. (2013). Clash! 8 cultural conflicts that make us who we are. New York: Penguin Books.

Maxi-Peel Skin Care. (2020). Maxi-peel skin care advertisement. Facebook. https://www.facebook.com/MaxiPeelSkinCare. Accessed on January 3, 2020.

Moya, P., \& Markus, H. (2010). Doing race: An introduction. In P. Moya \& H. Markus (Eds.), Doing Race: 21 essays for the twenty-first century (pp. 1-102). New York: Norton.

National Public Radio podcast. (2009). Skin whitening a global pratice. National Public Radio. https://www.npr.org/templates/story/story.php?sto $\mathrm{ryId}=106419771 \& \mathrm{t}=1589894655575$. Accessed on May 19, 2020.

Oksala, J. (2016). Affective labor and feminist politics. Signs, 41(2), 281-303. https://doi.org/10.1086/682920.

Op den Kamp, J., \& Sanchez, G. (2014). A look at skin-whitening: Natural Lang. The Philippines. https://vimeo.com/110724981.

Philippines Food and Drug Administration. (2019). PFDA Advisory 2019-182. Unsafe use of Glutathione as skin lightening agent. Philippines Food and Drug Administration. https://www.fda.gov.ph/?s=glutathione+injection. Accessed on May 19, 2020. 
Philippines Statistics Authority. (2013). The Philippine Statistical Act of 2013. Philippines Statistics Authority. https://psa.gov.ph/content/philippine-statis tical-act-2013. Accessed on January 3, 2020.

Pingol, A. (2001). Remaking masculinities. Diliman, Quezon City: University of the Philippines Press.

Rabin, R., \& Hsu, T. (2018). Johnson \& Johnson feared baby powder's possible asbestos link for years. New York Times. https://www.nytimes.com/2018/ 12/14/business/baby-powder-asbestos-johnson-johnson.html. Accessed on January 3, 2020.

Reyes-Velarde, A. (2019). Woman hospitalized with mercury poisoning after using face cream from Mexico. Los Angeles Times. https:/www.latimes.com/ california/story/2019-09-13/woman-hospitalized-with-mercury-poisoningafter-using-face-cream-from-mexico. Accessed January 3, 2020.

Salanga, G. (2018). Ruby ibarra: The battlecry of the modern Filipina warrior. Vesti Conversations. https://www.vesticonversations.com/all/2018/ 8/8/ruby-ibarra-the-battlecry-of-the-modern-filipina-warrior. Accessed on January 8, 2020.

Saraswati, L. A. (2013). Seeing beauty, sensing race in transnational Indonesia. Honolulu: University of Hawai'i Press.

Sunder Rajan, K. (2006). Biocapital: The constitution of postgenomic life. Durham, NC: Duke University Press.

Taqueban, E. (2018a). Armed with red lipstick. Fieldsights, Cultural Anthropology. https://culanth.org/fieldsights/armed-with-red-lipstick.

Taqueban, E. (2018b). Lipstick tales: Beauty and precarity in a southern Philippine boomtown (Doctoral dissertation, Universiteit van Amsterdam, Anthropology department, Amsterdam). https://dare.uva.nl/search?identifier=d21 c374b-f1f5-459d-a883-5c3e62330a99.

The Daily Posh. (2014). SkinWhite launches the \#betterme campaign. The Daily Posh. https:/www.thedailyposh.net/2014/12/skinwhite-launches-bet terme-campaign.html. Accessed on January 8, 2020.

Thompson, L. (2013). Aesthetics and empire: The sense of feminine beauty in the making of the US imperial archipelago. Culture \& History Digital Journal, 2(2), e027. https://doi.org/10.3989/chdj.2013.027.

Unilever. (2020). Unilever evolves skin care portfolio to embarce a more inclusive visoin of beauty. Uniever. https://www.unilever.com/news/press-releases/ 2020/unilever-evolves-skin-care-portfolio-to-embrace-a-more-inclusivevision-of-beauty.html?utm_source=UT\&utm_medium=Social\&utm_cam paign=AlwaysOn. Accessed on 26 June 2020. 
UP Diliman Information Office. (2018). Kat(h)awan: UP Diliman celebrates the Filipino body. UP Diliman Information Office. https://upd.edu.ph/kat hawan-up-diliman-celebrates-the-filipino-body/. Accessed January 3, 2020.

Vengill Gutierrez. (2012). Lactacyd white intimate flash mob @ food court festival mall Alanbang. YouTube. https://www.youtube.com/watch?v=7t0G7lmcyIk. Accessed on January 3, 2020.

Open Access This chapter is licensed under the terms of the Creative Commons Attribution 4.0 International License (http://creativecommons.org/ licenses/by/4.0/), which permits use, sharing, adaptation, distribution and reproduction in any medium or format, as long as you give appropriate credit to the original author(s) and the source, provide a link to the Creative Commons license and indicate if changes were made.

The images or other third party material in this chapter are included in the chapter's Creative Commons license, unless indicated otherwise in a credit line to the material. If material is not included in the chapter's Creative Commons license and your intended use is not permitted by statutory regulation or exceeds the permitted use, you will need to obtain permission directly from the copyright holder. 